\title{
Editorial by the editors and the editorial board
}

The year 2018 marks the $10^{\text {th }}$ anniversary of eco.mont-Journal on Protected Mountain Areas Research and Management. Since protected areas in mountain regions want not only to preserve valuable natural assets but also to promote and to develop strategies for sustainable development, it was the journal's goal from the outset to provide insights into ecological, cultural and economic diversity in mountain protected areas. This aim is achieved by publishing research on mountain protected areas globally to managers of protected areas, scientists, politicians and the interested public, and may provide the basis for decision-making processes. Becoming an open access journal helped us to reach out further.

The journal was founded in 2008 as a joint initiative of the Alpine Network of Protected Areas (ALPARC), the International Scientific Committee on Research in the Alps (ISCAR), the Austrian Academy of Sciences and the University of Innsbruck. Since then, the journal has been jointly funded by the Austrian Academy of Science and the University of Innsbruck, and published online by the Austrian Academy of Sciences Press and in print by innsbruck university press.

In 2006, ISCAR and ALPARC joined forces, establishing a common working group for Alpine Protected Area Research (ISCAR-P), which comprises scientists and professionals working in, with and / or for protected areas. ISCAR-P supports research activities by cooperating in the organization of the Symposium for Research in Protected Areas, maintaining the database on research in mountain protected areas, and organizing workshops on current topics. eco.mont also recruits to its editorial board from among members of ISCAR-P.

The journal's first issue was published after a year of preparatory work by the editors, the editorial office and the editorial board. Since then, eco.mont has been published biannually, presenting research results, case studies, reports on management and policy issues, news and book reviews. Altogether, 210 articles in 20 issues have so far been published. A special issue was dedicated to socio-economic issues concerning large protected areas in the Alps.

The topics covered and the specific protected areas examined during the 10 years since the journal's first issue are illustrated in Table 1. We have also added missing topics to the table, which were identified by looking at the subjects presented at the International Symposium for Research in Protected Areas (November 2017) and through an on-line survey we conducted in December 2017. Absent topics include biogeography, economics, geomorphology and hydrology. The most frequently covered topics concern management and tourism, followed by natural science. We would be especially interested to receive submissions by new and known authors in those subject areas that we have identified as absent from the journal's content.

Altogether, 86 protected areas in 33 countries have been discussed. The precise protected statuses of these areas are: wilderness areas (IUCN I category), national parks (IUCN II category), protected landscapes (IUCN category V), UNESCO World Heritage Sites, UNESCO biosphere reserves, Natura 2000 areas, protected areas with a specific local protection status, private protected areas, Europarcs and Geoparks.

The first issues covered mainly Alpine protected areas, but in time eco.mont became more global, examining protected areas from mountain ranges including the Carpathians and the Andes, and in countries such as Turkey and China. We have twice published articles from non-mountain protected areas when the topic was also of interest for mountain protected areas. These papers concerned ecosystem services and urbanization.

The journal is cited with increasing frequency and has a current impact factor of 0.333 . It has been on open access since 2015 and is listed in the Directory of Open Access Journals (DOAJ).

An on-line survey conducted in December 2017 amongst 1938 readers and authors of eco.mont yielded 136 responses from 36 countries, mostly from Europe, but also from South and North America, Africa and Asia. Although the response rate of $7 \%$ is not very high, the answers provide us with general information on how eco.mont is perceived.

The expertise of the respondents is as far ranging as the topics in Table 1. Most of the respondents are academics working at a university or in a research institute (63\%); only $15 \%$ work in management or as scientists in PAs (Figure 1).

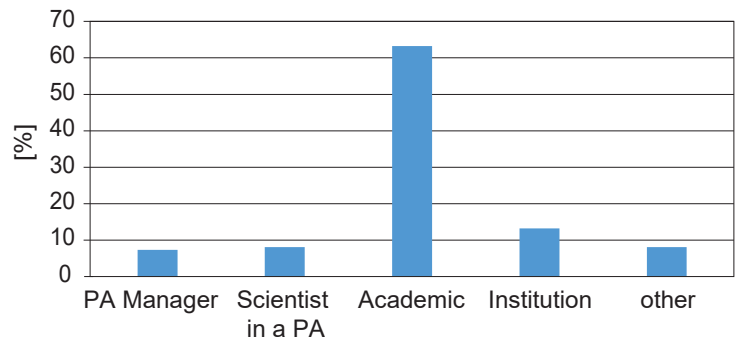

Figure 1 - Work environment of the respondents. $P A-$ protected area, $N=136$
Most of the respondents have been actively involved in the management of, or research in, protected areas for more than 5 years (Figure 2), and for $79 \%$ of the respondents, eco.mont is an important asset for their work. While the ratings for the quality of the articles are satisfactory, we can certainly strive for better (Figure 3).

$53 \%$ of the respondents would like to read more scientific articles in future, and $42 \%$ would like more articles on management and policy issues. $46 \%$ of the respondents want to read more articles about mountain protected areas anywhere, compared to $33 \%$ who 
Table 1 - Topics and sub-topics covered by eco.mont in the last 10 years (issues 1-1 to 10-1, including one special issue). We have also identified subjects which have not yet been covered (in italics) by going through topics presented at the International Symposium for Research in Protected Areas (November 2017) and through an on-line survey conducted in December 2017. NaP - National Park, BR - UNESCO biosphere reserves, WH - UNESCO World Heritage Sites

\begin{tabular}{|c|c|c|}
\hline Topic & Sub-topic & $\begin{array}{l}\text { Sub-topics which haven't } \\
\text { yet been covered }\end{array}$ \\
\hline Biodiversity & climate change, conservation, health, management, perception of change, visitors, inventory & \\
\hline Biogeography & not yet covered & \\
\hline Botany & botany, conservation, land-use change, monitoring, succession, ethnobotany, health benefits & $\begin{array}{l}\text { ethnobotany, colonization, } \\
\text { dispersal, } \mathrm{CO}_{2} \text { flux }\end{array}$ \\
\hline Citizen science & monitoring & \\
\hline Climate change & adaptation, management, monitoring & vulnerability, neobiota \\
\hline Conservation & conflicts, history, management, regional development, transborder & \\
\hline Economy & not yet covered & $\begin{array}{l}\text { landscape economy in moun- } \\
\text { tain regions }\end{array}$ \\
\hline \multicolumn{3}{|l|}{ Ecological network } \\
\hline Ecosystem services & & resilience \\
\hline Geoinformation & GIS and information management & $\begin{array}{l}\text { remote sensing, information } \\
\text { technology }\end{array}$ \\
\hline Geology & geodiversity, geology, karst & $\begin{array}{l}\text { geomorphology, erosion } \\
\text { dynamics }\end{array}$ \\
\hline Governance & $\begin{array}{l}\text { environmental governance, civil society organizations, participatory approach, stakeholder } \\
\text { involvement }\end{array}$ & $\begin{array}{l}\text { best practice, governance and } \\
\text { ecosystem services }\end{array}$ \\
\hline Hydrology & not yet covered & $\begin{array}{l}\text { catchment and stream net- } \\
\text { work management, flood risk }\end{array}$ \\
\hline Limnology & climate change, limnology, river & \\
\hline Management & $\begin{array}{l}\text { conservation, education, human impact, hydropower, land-use changes, mapping, monitor- } \\
\text { ing, renewable energy, research, residents, urbanization, World Heritage Sites }\end{array}$ & $\begin{array}{l}\text { hunting, perspectives, policies } \\
\text { and strategies }\end{array}$ \\
\hline Mobility & sustainability & \\
\hline Monitoring & Alpine waters, botany, climate change, zoology & \\
\hline \multicolumn{3}{|l|}{$\begin{array}{l}\text { Nomination of protected } \\
\text { areas }\end{array}$} \\
\hline Parks and people & & $\begin{array}{l}\text { acceptance, parks objectives } \\
\text { in transformation, reconciling } \\
\text { park management with local } \\
\text { and regional development }\end{array}$ \\
\hline \multicolumn{3}{|c|}{$\begin{array}{l}\text { Private mountain protected } \\
\text { areas }\end{array}$} \\
\hline Programmes & $\begin{array}{l}\text { Alpine Convention, EuroMAB Conference, Europarc, LTSER, MAB Programme, National Parks } \\
\text { Austria, Working Group UNESCO World Heritage of the Alpine Convention }\end{array}$ & \\
\hline Regional development & agriculture, recreational landscapes, sustainable development & sustainable agriculture \\
\hline Research & societal research, biosphere reserve research & \\
\hline Social media & science communication & \\
\hline \multicolumn{3}{|l|}{ Social tensions } \\
\hline \multicolumn{3}{|l|}{ Soil science } \\
\hline Tourism & $\begin{array}{l}\text { appropriate behaviour, crowding, crowding \& monitoring, environmental behaviour, impact, } \\
\text { infrastructure, monitoring, perception, regional development, spatial behaviour, sustainable } \\
\text { tourism, trail management, visitor segmentation, visitor profiling, wastewater, winter sport \& } \\
\text { wildlife }\end{array}$ & \\
\hline Training \& education & advanced studies, summer school, school initiative, art \& science convergence & \\
\hline Zoology & $\begin{array}{l}\text { climate change, climate change \& endemism, colonization, endemism \& human impact, } \\
\text { habitat conservation, landscape management, succession, zoology }\end{array}$ & colonization, dispersal \\
\hline
\end{tabular}




\begin{tabular}{|c|c|c|}
\hline $\begin{array}{l}\text { Scientific } \\
\text { orientation }\end{array}$ & $\begin{array}{l}\text { No. of articles } \\
\text { covering this top- } \\
\text { ic in eco.mont }\end{array}$ & Protected areas and country \\
\hline $\begin{array}{l}\text { Natural \& social } \\
\text { sciences }\end{array}$ & 7 & Gesäuse NaP (AT), Großes Walsertal BR (AT), Mercantour NaP (FR), Orobie Bergamasche Regional Park (IT) \\
\hline Natural sciences & 8 & $\begin{array}{l}\text { Gurgler Kamm BR (AT), Kancheniunga Conservation Area (NP), LTER site Eisenwurzen (AT), Parco dell'Adamello } \\
\text { (IT), Pelister } \mathrm{NaP}(\mathrm{MK}) \text {, Swiss } \mathrm{NaP}(\mathrm{CH})\end{array}$ \\
\hline Social sciences & 1 & \\
\hline $\begin{array}{l}\text { Natural \& social } \\
\text { sciences }\end{array}$ & 8 & $\begin{array}{l}\text { Berchtesgaden NaP (DE), Cinturón Andino BR (CO), Erins NaP (FR), Hohe Tauern NaP (AT), Huascarán NaP (PE), } \\
\text { Katunskiy BR (RU), Pirin NaP (BG), Sierra Nevada de Santa Marta BR (CO) }\end{array}$ \\
\hline Social sciences & 9 & $\begin{array}{l}\text { Hohe Tauern NaP (AT), Kastamonu-Bartin Küre Mountains NaP (TR), Mercantour NaP (FR), Munessa Shashamene } \\
\text { Forest (ET), National Reserve Praded (CZ), Wienerwald BR (AT) }\end{array}$ \\
\hline & 0 & \\
\hline $\begin{array}{l}\text { Natural \& social } \\
\text { sciences }\end{array}$ & 3 & Berchtesgaden NaP (DE), Gesäuse NaP (AT) \\
\hline Natural sciences & 2 & Lake Neusiedl / Fertö Hanság NaP (AT / HU), Muránska Planina NaP (SK) \\
\hline Technical sciences & 1 & \\
\hline Natural sciences & 3 & Berchtesgaden NaP (DE), Les Contamines-Montioie Natural Reserve (FR), Una NaP (BA) \\
\hline Social sciences & 9 & $\begin{array}{l}\text { Carpathian BR (UA), Großes Walsertal BR (AT), Montseny Natural Park (ES), Samothraki BR (GR), Swiss Alps } \\
\text { Jungfrau-Aletsch WH (CH), Tusheti Protected Areas (GE), Xinjiang Tianshan WH (CN) }\end{array}$ \\
\hline & 0 & \\
\hline Natural sciences & 5 & Makira Protected Area (RM), Swiss NaP (CH) \\
\hline $\begin{array}{l}\text { Natural \& social } \\
\text { sciences }\end{array}$ & 29 & $\begin{array}{l}\text { Berchtesgaden NaP (DE), Dadia NaP (GR), Dürrenstein Wilderness Area (AT), Gesäuse NaP (AT), Hohe Tauern } \\
\text { NaP (AT), llgaz Nountain NaP (TR), Jiu River Gorge (RO), Kalkalpen NaP (AT), Kakamega Forest (KE), La Cam- } \\
\text { pana-Peñuelas BR (CL), Mont Avic Nature Park (IT), Rhön BR (DE), Salzburger Lungau \& Kärntner Nockberge BR } \\
\text { (AT), Schwäbische Alb BR (DE), Santuario de la Naturaleza del Campo Dunar de la Punta de Concón (CL), Simien } \\
\text { Mountain NaP (ET), Swiss NaP (CH) }\end{array}$ \\
\hline Social sciences & 2 & Dolomites WH (IT) \\
\hline Natural sciences & 4 & Aigner Park (AT), Entlebuch BR (CH), Swiss Alps Jungfrau-Aletsch WH (CH) \\
\hline Social sciences & 3 & Dolomites WH (IT), Salzburger Lungau \& Kärntner Nockberge BR (AT) \\
\hline & 4 & Stilfserioch NaP (IT), Val Müstair BR (CH), Vanoise NaP (FR) \\
\hline Social sciences & 2 & \\
\hline & 9 & \\
\hline Social sciences & 6 & Riding Mountain BR (CA), Triglav NaP (SI) \\
\hline & 3 & \\
\hline Social sciences & 1 & \\
\hline Social sciences & 3 & Kavkazki Zapovednik WH (RS), Nanda Devi BR (IND), Rwenzori Mountains NaP (UG) \\
\hline Natural sciences & 2 & Hohe Tavern NaP (AT), Sabalan National Natural Monument (IR) \\
\hline Social sciences & 30 & $\begin{array}{l}\text { Alpine Nature and Geopark Styrian Eisenwurzen (AT), Berchtesgaden NaP (DE), Entlebuch BR (CH), Gesäuse NaP } \\
\text { (AT), Hell's Canyon National Recreation Area (US), Huilo Huilo Biological Reserve (CL), Köprülü Canyon NaP (TR), } \\
\text { Mt Kenya WH (KE), Mt Kilimanjaro WH (TZ), Mount Taibai National Nature Reserve (CN), Natura } 2000 \text { Allgäuer } \\
\text { Hochalpen (DE), Pieniny Mts NaP (PL), Saxon Switzerland NaP (DE), Sierra Nevada de Santa Marta BR, Swiss NaP } \\
\text { (CO), Tatra NaP (SK), Triglav NaP (SLI), Tunca Valley Natural Park (TR), Val Müstair BR (CH), Wienerwald BR (AT) }\end{array}$ \\
\hline Social sciences & 6 & Beverin Nature Park $(\mathrm{CH})$, Salzburger Lungau BR (AT) \\
\hline Natural sciences & 14 & $\begin{array}{l}\text { Gesäuse NaP (AT), Jinggangshan National Nature Reserve (CN), Kalkalpen NaP (AT), Monte Barro Regional Park } \\
\text { (IT), Mount Nemrut NaP (TR), Natura } 2000 \text { Kirchfeld plateau (AT), Swiss NaP (CH), Wienerwald BR (AT), Vâlsan } \\
\text { River valley (RO) }\end{array}$ \\
\hline
\end{tabular}




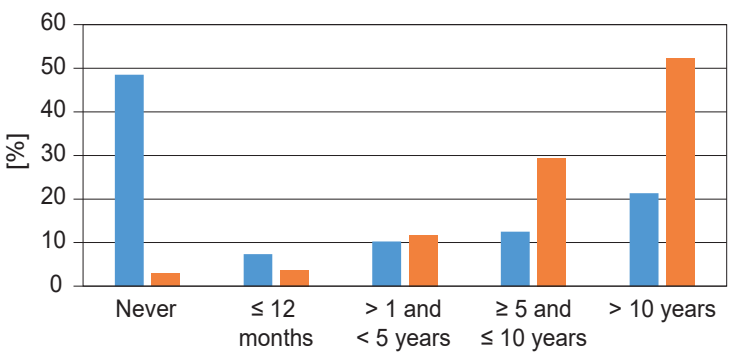

Active involvement in the management of a protected area

Active involvement in research in protected areas

Figure 2 - Active involvement in the management of, or research in, protected areas. $N=136$

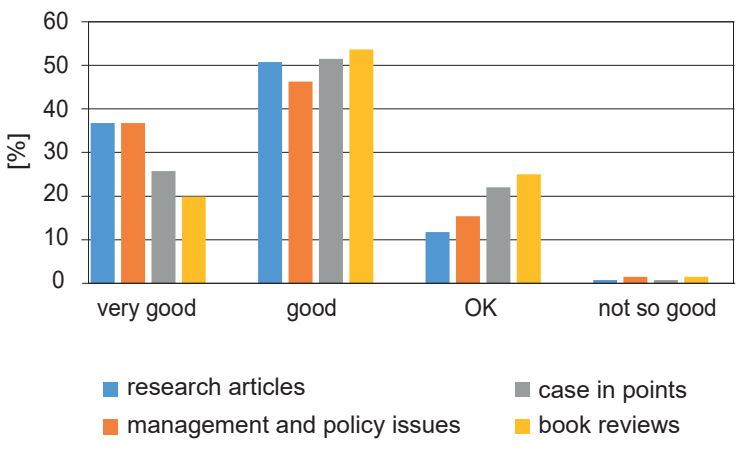

Figure 3 - Ratings of the quality of the articles. $N=136$

are interested in reading articles about mountain protected areas in the Alps specifically. The results show that it was, by and large, participants who appreciate eco.mont who took part in the survey, and so we must work harder to become visible outside of this community.

We will be striving hard in the future to increase the journal's impact factor, and for an enhanced visibility in the community. We hope that the research findings that we publish in eco.mont will help evidence-informed decision making processes.

We would like to thank our partners in the scientific community especially for their continued submissions and their work in the peer review process.

To celebrate our $10^{\text {th }}$ anniversary, we invited authors to write reports on mountain research in their country, a mountain region or a National Park. In a special section of this issue, therefore, we are pleased to publish an article by Morten Clemetsen \& Knut Bjorn Stokeke on Norway, one that focuses on the Carpathians by Juraj Švajda, and a paper by Christian Komposch \& Daniel Kreiner on research in the Gesäuse National Park (Austria). In addition, the editorial team of the journal Mountain Research and Development (MRD) provide an overview of areas of research covered in academic journals that focus on mountain areas.

Other than for these additions, the issue is arranged in the usual way. Hu et al. write about fish species abundance and distribution in mountain streams in the Wuyishan National Nature Reserve (China). Tommaso Sitzia et al. discuss how abandoning traditional forest activities favours beech at the expense of silver fir in their study area in Northern Italy. Adelheid Humer-Gruber identifies farmers' willingness to participate in Alpine biosphere reserves and their attitudes towards biosphere reserves and nature conservation. Armin Kratzer provides an overview of publications and major topics in Biosphere Reserve research and its international research network. Agata Warchalska-Troll examines whether the presence of Natura 2000 sites affects spatial development at the local level.

A report written by Andreas Haller \& Hildegardo Córdova-Aguilar underlines the need to integrate cities and protected areas in planning and policy making in the Andes. We move to Austria with Anna-Sophie Pirtscher, who tells us about the implementation of specific management measures and monitoring to improve Natura 2000 habitats for aquatic creatures and amphibians. Siegrist et al. give an account of a hiking study across the Alps made between June and September 2017 and show how the image of the Alps had changed since 1992, when they hiked a similar route. Finally, Andrés Moreira-Muñoz et al. report from Chile on the $1^{\text {st }}$ symposium on Biosphere Reserves in transition towards sustainability, held in October 2017.

Last but not least, we would like to say good bye to Kristina Bauch who has to leave the Editorial Board of eco.mont. She was a member of the Editorial Board from the very beginning. She has also put her extraordinary expertise and experience into organizing the Symposium for Research in Protected Areas. This symposium goes back to an idea of Kristina Bauch's and was held for the first time in 1996. Since then Kristina has organized it five more times. She will monitor the further development of eco.mont as a private senior consultant. Thank you Kristina for your continued support.

Now we wish you all a pleasant reading of this milestone issue and hope for fruitful future collaboration.

\section{Authors}

Valerie Braun

is a biologist and works at the Institute for Interdisciplinary Mountain Research and is managing editor of eco.mont.

\section{Martin Coy}

is a professor of Applied Geography at the University of Innsbruck. He studied in Frankfurt / Main and Paris and holds a PhD from Tübingen University. His main research is on resource conflicts, sustainable regional and urban development and biosphere reserves with a focus on Brazil. In 2016, he became co-editor of eco.mont. 


\section{Massimo Bocca}

has been the Director of Mont Avic Natural Park since 1991 and is a member of ALPARC. He has a degree in agronomic sciences and a doctoral thesis in entomology. He is the author or co-author of more than 40 scientific zoological papers on entomology, herpetology, and especially ornithology.

Jean-Jacques Brun

has an MSc in ecology and a PhD in soil ecology. He is currently a research professor at Irstea-Grenoble Alpes University, researching on the role of various forms of humus, organic matter and soil fauna as indicators of the impacts of global change on mountain ecosystems. He has worked as the French co-delegate at ISCAR.

\section{Leopold Füreder}

is a professor at the Institute of Ecology, University of Innsbruck, Austria. He holds a doctorate in the field of limnology and tropical ecology, and habilitated in limnology and zoology. Key research topics are effects of climate change on freshwater ecosystems, trophic ecology, indicators of environmental status and change, and aquatic conservation. His research focuses on regions of the Alps, Eastern Europe, Svalbard, Central America and Asia.

\section{Matej Gabrovec}

is a researcher at the Anton Melik Geographical Institute, Research Centre of the Slovenian Academy of Sciences and Arts, Ljubljana, and Assistant Professor at the Faculty of Humanities of the University of Primorska in Koper. His main research areas are land-use changes, transport geography and geomorphology.

\section{Günter Köck}

is Secretary-General of the Austrian MAB National Committee, former Vice-Chair of the UNESCO MAB Programme, and the Austrian delegate to the European Alliance of Global Change Research Committees. He is also a member of the Scientific Board of Hohe Tauern National Park, as well as one of the Austrian delegates to the International Scientific Committee for Research in the Alps (ISCAR). In 2009, he became co-editor of eco.mont.

\section{Guido Plassmann}

has been studying, living and working in the Alps since 1985. His studies in Alpine geography, economics and history have given him a solid appreciation for complex Alpine nature conservation processes. He has led and coordinated the Alpine Network of Protected Areas (ALPARC) since 1995. Over a period of 25 years, he has realized numerous projects dealing with the management of protected areas, ecological connectivity, sustainable regional development and broad public communication in the Alps and Carpathians.

\section{Roland Psenner}

is a professor of Limnology at the University of Innsbruck, Austria. He is an expert in eutrophication and phosphorus cycling, the biogeochemistry of acidification, the effects of global change on lakes. He is also an expert in aquatic microbial food webs and ice ecosystems. He has served as Dean of the Faculty of Biology and Vice Rector at the University of Innsbruck. He is currently president of Eurac Research in Bolzano (Italy).

\section{Thomas Scheurer}

is the executive secretary of the Swiss Interacademic Commission for Alpine Studies (ICAS), the International Scientific Committee on Research in the Alps (ISCAR), and the Research Council of the Swiss National Park, all located at the Swiss Academy of Sciences.

\section{Dominik Siegrist}

is a landscape planner and geographer who works for the HSR Hochschule für Technik Rapperswil in Switzerland.

\section{Astrid Wallner}

is the coordinator for research on Swiss parks. She studied social anthropology and geography at the University of Zurich (Switzerland) and has worked on the local acceptance of protected areas in Switzerland and Ukraine.

\section{Herbert Wölger}

received his academic education in Vienna at the University of Natural Resources and Life Sciences (Forestry and Wood Technology). After some years in the forestry and wood industry, he worked for a development project in a Biosphere Reserve in Argentina. He is currently the Managing Director of Gesäuse National Park. 


\section{Related projects according to the European Mountain Pool}

At the editorial office of eco.mont, we maintain the European Mountain Pool on research in European protected mountain areas. http://4dweb.proclim.ch/4dcgi/ProtAreas/en/BuildSearch_ ProtArea

eco.mont - Volume 10, Number 2, July 2018

Fish species abundance and distribution in Wuyishan National Nature Reserve, Jiangxi Province, China by Maolin Hu, Chaoyang Wang, Xiangyu Zhang, Rongbin Yuan, Aifang Zhang, Liuzheng Wu \& Shaoqing Jian

Where farmers see their role - Influence on sustainable regional development approaches in Alpine biosphere reserves by Adelheid Humer-Gruber

Natura 2000 sites in the Polish Carpathians vs local development: inevitable conflict? by Agata Warchalska-Troll

Urbanization and the advent of regional conservation: Huancayo and the Cordillera Huaytapallana, Peru by Andreas Haller \& Hildegardo CórdovaAguilar

A strangely-shaped protection area by Anna-Sophie Pirtscher
Related projects in the European Mountain Pool and eco.mont

Maolin Hu: Freshwater fish species richness and conservation of mountain streams in the Jinggangshan National Nature Reserve, China. CH-5384

Brigitte Allex: Einstellung der lokalen Bevölkerung zum Biosphärenpark Wienerwald. CH-6159

Fedir Hamor: Carpathian Biosphere Reserve (Ukraine): Towards Participatory Management. CH-5496

Michael Huber: Opponents, waverers or supporters: the influence of place-attachment dimensions on local residents' acceptance of a planned biosphere reserve in Austria. CH-6206

Adelheid Humer-Gruber: Biosphärenparks - Innovationsmotor oder Hindernis. Wahrnehmung und Sichtweise von Bäuerinnen und Bauern in Biosphärenparks. CH-5410

Florian Knaus: Akzeptanz, Identifikation und Engagement: Ansichten und Mitwirkung der Bevölkerung in UNESCO Biosphärenreservaten. CH-5986

Gerhard Weiss: The implementation of Natura 2000 in Austria - A European policy in a federal system. CH-6184

Andres Moreira-Munoz: Threats and challenges in a peri-urban transition zone. $\mathrm{CH}-5378$

Filippo Favilli: The Carpathian Ecological Network GIS approach to detect the landscape permeability for particular umbrella species. CH-5082

Barbara Dillinger: Strategies of wetland restoration in the Waasen/Hanság (northern Burgenland). CH5073

Günter Gollmann: Frogs in the city: problems of research and conservation of amphibians in Lobau (Vienna, Donau-Auen National Park). CH-5088 